\title{
Conflict Resolution Approaches of Jamaican Church Leaders
}

\author{
Davina Clarke, Ph.D. \\ Florida International University \\ 11200 SW 8th St, Miami, FL 33199, United States
}

\begin{abstract}
The study of conflict resolution has ballooned in the last few decades, but the literature remains sparse regarding leaders' perspectives of navigating conflict. Currently, researchers have not addressed the conflict experiences of Jamaican church leaders residing in South Florida. Using phenomenology and social construction theory, I explored the lived experiences of this population as they addressed conflict. Twenty-two church leaders were interviewed for an average of 45 to 60 minutes each. The data were transcribed, coded, and analyzed, yielding seven core themes. The study has merit for its useful insights for practitioners. In addition, the study has activated voices in academic literature that might otherwise have been silent.
\end{abstract}

Keywords: Conflict Resolution, Jamaica, Church, Religion, Organization, Phenomenology

\section{Introduction}

History is replete with conflict within religious groups in the United States. In fact, church conflicts are some of the most volatile conflicts within organizations (Greenwood, 2005). Church organizational conflict can cause several undesirable outcomes, including diversion from mission and goals, members' withdrawal from activities and friendship networks, diminished positive support, and heightened levels of negative interactions (Ellison, Krause, Shepherd, \& Chaves, 2009).These issues may multiply because many church leaders are not effectively equipped to deal with conflicts (Rediger, 1997).

Church leaders have typically faced tremendous amounts of stress, often resulting from their role and conflict situations (Whitson, 2014). This research study focused on a specific population of church leaders who were (a) Jamaican or of Jamaican origin, (b) resided in South Florida (c) practiced the Apostles' doctrine, (d) were between 18 and 44 years of age, and (e) had experienced conflict. Exploring church leaders' experiences with managing conflict could be critical to improving the direction of the church and the lives of the congregants and community members.

\section{Theory}

Social constructionists study how social contexts influence individuals, and existential phenomenologists focus on individuals and their experiences. Solomon (1972) noted the existentialist approach is based on the idea that each person decides who he or she is. Even though this may seem to conflict with a social constructionist perspective-that people are influenced by their environments - it does not mean the two theoretical perspectives conflict. Although individuals decide to be who they are, they are simultaneously being influenced by what is around them, including their social environments (Cooper, 2014). Thus, two theories that seem to oppose each other can exist symbiotically. Gergen (1992) argued that even though realism and constructionism seem to oppose each other, they could exist together. For instance, political correctness is a constructionist discourse, but realists employ it to defend their beliefs against constructionist attacks (Gergen, 1992). "In this sense there are no realists or constructionists per se[emphasis original], but cultural participants who adopt these and other discourse on various occasions as conversational exigencies prevail" (Parker, 1998, p. 153).

\section{Social Constructionism Theory}

Although most theories come from a specific school of thought, social constructionism comes from a wide array of research agendas, and its origin may have developed from the social sciences (Weinberg, 2014). Therefore, researchers should not consider social constructionism in narrow, simplistic terms. The theory involves historical, social, and cultural contexts, and encompasses how people construct ideas within these arenas (Burr, 2006). What people know of themselves, they know through language. Language is a collection of symbols that shape the way people view the world (Burke, 1966). "The person cannot pre-date language because it is language which brings the person into being in the first place" (Burr, 2006, p. 23). In addition, Burke (1966) wrote, 
We must use terministic screens, since we can't say anything without the use of terms; whatever terms we use, they necessarily constitute a corresponding kind of screen; and any such screen necessarily directs the attention to one field rather than another. (p. 50). Thus, the way people view the phenomena they experience depends on the language they use. People's thoughts, feelings, and experiences are all the result of language (Burr, 2006).

Gergen and Gergen (2013) recognized that people should share their constructed narratives, not keep them private. The process of self-disclosure opens people up to others, who are in turn affected. This outcome is expected because the self is a product of socialization and collective social life and is affected by the external environment (Weinberg, 2014, p. 104). In this process, people are co-actors in the construction of their stories (Burr, 2006). Therefore, what they think of themselves is formed in part by the stories they relate to each other. Lock and Strong (2010) claimed that personal subjectivity is at the core of experiences. Even personality exists because of how people act when they interact with others (Burr, 2006). For example, if a person were friendly, shy, or aggressive, this would only become apparent when he or she was with others. If the person lived alone, encountering no one, knowing whether any of these characteristics applied to the person would be impossible (Burr, 2006).

\section{Phenomenology}

Phenomenology refers to a description of common experiences (phenomena) shared by a group of people; the description allows readers to imagine the lived experiences of the participants, to see things the way they occurred (Moustakas, 1994). Phenomenology can be defined as "the study of consciousness as experienced from the first-person point of view. In phenomenology, "every intending has its intended object" (Sokolowski, 2000, p. 8). Intentionality from a phenomenological perspective refers to the theory of knowledge; thus, in phenomenology, "intending means the conscious relationship we have to an object" (Sokolowski, 2000, p. 8). The Greek expression phainomenon, from which the term "phenomenon" derives, comes from the verb phainesthai, meaning "to show itself" (Heidegger, as cited in Sokolowski, 2000, p. 8). Thus, phainomenon means "what shows itself, the self-showing, the manifest" (Heidegger, as cited in Brogan, 2005, p. 28). All the participants in the study shared the common experiences of (a) having a Jamaican heritage; (b) residing in the United States; (c) serving as a leader in a religious organization; and (d) experiencing conflict.

Although existential phenomenology is a different branch, it should not be thought of as completely separate from Husserl's approach; rather, it is a redirection from his original philosophy (Solomon, 1972). Contrary to what some scholars believe, existential phenomenology not only concerns the individual, but also the universal and the conceptual - each individual must be able "to act, to plan, to use language, to evaluate, and perhaps most important of all, to ask who he is and what he ought to $d o "$ (Solomon, 1972, p. 177).

Several philosophers have influenced existential phenomenology, including Sartre, Merleau-Ponty, and Heidegger (Smith, 2013). Sartre is credited as a major figure following Husserl (Lee \& Mandelbaum, 1967). Merleau-Ponty is known for his philosophy of the bodily experience in perception (Smith, 2013). He believed that in order to have perception of something, it must be embedded in a phenomenon; there must be a distinction between what is being perceived as "something," and the context, "the field" (Smith, p. 9). Therefore, if an area is homogeneous, there is nothing to perceive (Merleau-Ponty, 1945/2012). Heidegger, who like other existential phenomenologists adapted some fundamental changes to Husserl's original ideology (Smith, 2013). Heidegger looked at phenomenology from a subjective point of view, whereas Husserl used a positivist approach (Smith, 2013). In addition, Heidegger rejected the idea that researchers could "bracket" their experiences because he believed people are a part of the experience (Smith, 2013), whereas Husserl (1901) thought researchers could objectively separate from the experience.

Bracketing, in phenomenology (also referred to as epoché), means to distance oneself from a situation and view it from a purely objective standpoint (Sokolowski, 2000).Although I rejected bracketing from Husserl's perspective, I believe researchers must allow full descriptions from the participants' perspectives without including any personal preexisting assumptions while remaining neutral and avoiding imposing preexisting beliefs. Sokolowski (2000) wrote, "The epoche in phenomenology is simply the neutralizing of natural intentions that must occur when we contemplate those intentions" (p. 49). Although scholars have agreed that it is necessary to look at a situation with a fresh pair of eyes, it impossible to bracket ones' experiences completely (Giorgi, 2009). Researchers can hardly be completely objective: Even the simplest "factual perceptions" are not absolute, but are considered through relational terms (Merleau-Ponty, $1945 / 2012$, p. 4). These differences in perspective in phenomenology are not new, but several phenomenological terms or concepts can have different interpretations. 
Although terms in phenomenology may have different meanings, the meanings are consistent among the philosophers who have used them. For example, both Husserl and Kant used terms like synthesis, transcendent, transcendental, intuition, and idealism, but these terms meant different things for each philosopher (Zaner \& Ihde, 1973). Even within the same school of phenomenology, differences in meaning have appeared for a concept or word. For example, within the existentialist perspective, different ideas of freedom have emerged. From Sartre's perspective, freedom is the annihilation of the past, separating the self from itself and existence from having been (Solomon, 1972).

Existentialists have differentiated themselves in many ways from the Husserlian approach. First, early existential phenomenologists were concerned with examining how people define and use their consciousness of the world, whereas Husserl looked at what people know about objects in the world (Solomon, 1972). Second, besides their position on human action, the existentialist differed from Husserl in interpretation of the epoché (Solomon, 1972). Husserl believed people could suspend their beliefs, but the existential phenomenologist believed it was impossible to suspend belief in the world completely; therefore, researchers cannot bracket their experiences because they are a part of the world (Solomon, 1972). As a result of the rejection of epoché, existential phenomenology has been equated with ontology (Solomon, 1972), which deals with the nature of being (Sokolowski, 2000). Third, Husserl (1901) believed things come into existence based on reflection, while Heidegger (1927) believed that things could exist before people are aware that they exist (ontic versus ontological structures). Another factor, Sartre argued, was that people do not always reflect on their experiences, whereas Descartes and Husserl argued as if "the self" was an internal object that inhabited consciousness; as Heidegger wrote, "the self is not primitive" (not necessary to consciousness; Solomon, 1972, p. 35). Another point of disagreement was that although Husserl believed that consciousness depended wholly on what was given to it, the opposing claim was that consciousness created its world (Solomon, 1972).

\section{Method}

Researchers use the phenomenological approach to explore individuals' lived experiences of a certain phenomenon (Moustakas, 1994). For this research study, the phenomenon was the experience of Jamaican church leaders in conflict. The phenomenological approach "consists of 'what' they experienced and 'how' they experienced it (Moustakas, 1994), which allows the participants to feel really understood (Van Kaam, 1966). The phenomenological approach fosters an in-depth understanding of the participants' lived experiences through asking participants relevant open-ended questions concerning their experiences (Kvale \& Brinkmann, 2009). Intentionality is a key component in the sense that phenomenology focuses on a first-person perspective of a particular phenomenon.

The phenomenological approach should be void of assumptions, allowing the participants' voices to emerge as they relate their stories. While it is important to remain neutral as the participants reveal their life stories, Heidegger rejected the idea that researchers could "bracket" their experiences because he believed that people are a part of the experience (Smith, 2013). As Sokolowski (2000) puts it, "bracketing" means neutralizing our intentions; therefore, while I cannot suspend belief in the world completely (Solomon, 1972), I can neutralize them so that I do not make any assumptions. Essentially, a co-constructing of the research experience takes place. Even though the interviewer has the research objective and scope in mind, the participants decide what they will share and at what depth (Kvale \& Brinkmann, 2009). With this approach in mind, phenomenology was the most appropriate method for its ability to generate a rich description of the participants' experiences as they co-constructed their own narratives.

After gaining access to the site, I addressed the leaders collectively. First, I explained the purpose of the research, described the criteria for the participants, and explained how they could make contributions to the field of conflict resolution. I reminded them that their participation was completely voluntary and that no compensation would be provided. Of the 30 leaders who were qualified to participate in the study, 22 accepted. Those participants who indicated their interest met with me face-to-face to schedule interviews. I asked participants to complete a brief survey to verify they qualified for the study, and in the process, I was also able to obtain additional data to complete the analysis. These additional data included demographic information such as affiliation to Jamaican ethnicity, age, gender, leadership title, and length of service. As confirmed by the participants, all were Jamaican or derived from Jamaican households. Most resided in Broward County, with the remaining few from the Palm Beach and Dade counties. Their ages ranged from 18 to 44, with the majority between 25 and 40 years of age. Research has indicated each generation has its own religious orientation (Fowler, 2009); therefore, religious orientation was an important demographic variable. The number of participants was selected based on the point at which data saturation occurred, which means no new themes emerged from the data (Creswell, 2007). 
The organization for the study is a multicultural, nondenominational church whose members believe in the practices developed by the early Apostles in the church. I chose to conduct interviews with a specific population who had similar experiences. Kvale and Brinkmann (2009) recommended following seven stages when designing and implementing interview studies.

Stage 1: Thematizing. In this stage I looked at the purpose of this study and the research questions to ensure the right approach was used. The central research question was, "How do the lived experiences of Jamaican church leaders influence their conflict resolution approaches?

Stage 2: Designing. It was important to look at the overall design of the study to see whether all the resources were available to carry out the research and discern whether the research was worth pursuing. I consulted with the gatekeeper to gain access to the site.

Stage 3: Interviewing. During the face-to-face interviews I noted not only the content, but also how messages were expressed. I was mindful of nonverbal cues and ensured that the meaning of the participants was relayed correctly so that the quality of the interview was not compromised.

Stage 4: Transcribing. This stage addressed the transcription of the data from audio file to the written text. A secured transcription service provider and I shared the transcribing of the interviews into dialogue format. I transcribed all the recorded data verbatim, including vocal fillers and pauses. In addition, I noted nonverbal behavior such as gestures, postures, and body movements, which provided depth to the meaning.

Stage 5: Analyzing. The essence of the interview must be categorized and coded in a meaningful way so that the data was interpreted correctly. I divided the interview transcription of the Jamaican church leaders into parts to determine the "units of meaning" within the descriptions. I reread the texts and indicated a mark when I noted a shift in meaning (Giorgi, 2009). I used the Moustakas' seven steps phenomenological analysis, which will be discussed in the next section.

Stage 6: Verifying.In this stage focused on generating reliable, valid, and relevant information. I remained neutral throughout all 22 interviews while allowing them to express their experiences in conflict. Although I had my own biases as a Jamaican church leader, I had to set aside my suppositions. Not only was I careful to approach the study with a fresh viewpoint, but I continued to collect data until saturation was reached to produce strong themes.

Stage 7: Reporting.I reported the findings of the research, which contained usable data while protecting the integrity and confidentiality of the participants. The electronic version of the data was stored in a password-protected computer to secure its contents.

\section{Results}

From a detailed look at each participant, it was evident that each tried to address conflict the best way they could. No noticeable differences emerged between the conflict resolution techniques used by men and women. More than half the participants approached conflict from an optimistic perspective. For these leaders, conflict was an opportunity to solve problems; however, whether a resolution was achieved depended on the parties in the conflict. Of the 22 participants, 12 embraced solving problems. Of the 12 participants in this category, five participants looked at conflict as an open door for conversation; six participants looked at conflict as an opportunity to work on the same team, and five believed the parties determined the solution. Strategies such as confronting the issue, getting specific facts, adapting to the other party or the situation, applying Biblical principles, using effective communication skills, getting help from others, and mediating disagreements were strategies used by 21 of the 22 participants. Table 1 shows an example of some of the responses from the participants. 
Table 1 Perspective on Identity and View of Conflict

\begin{tabular}{|c|c|c|}
\hline Leaders & View of conflict & Verbatim examples \\
\hline Jessica & Positive & $\begin{array}{l}\text { "Spending time with people really getting to } \\
\text { know them helps diffuse conflicts." }\end{array}$ \\
\hline Chris & Positive & $\begin{array}{l}\text { "Conflict is positive when the parties } \\
\text { involved are willing to come to a solution." }\end{array}$ \\
\hline Riley & Negative & $\begin{array}{l}\text { "I am not a confrontational person, so I tend } \\
\text { to not want that around me." }\end{array}$ \\
\hline Catherine & Positive & "I would go and approach them." \\
\hline Eva & Positive & $\begin{array}{l}\text { "Try to re-approach it- but, more calmly, } \\
\text { and try to, listen more." }\end{array}$ \\
\hline Anthony & Positive & $\begin{array}{l}\text { "I'm going to put the ball in my court so the } \\
\text { person doesn't automatically get defensive." }\end{array}$ \\
\hline Juan & Positive & $\begin{array}{l}\text { "A lot of times you can resolve conflict by } \\
\text { communicating effectively." }\end{array}$ \\
\hline Colette & Negative & $\begin{array}{l}\text { "I try to stay far away. I am not getting } \\
\text { involved!" }\end{array}$ \\
\hline Stewart & Positive & "Conflict is a learning experience." \\
\hline Marianne & Negative & $\begin{array}{l}\text { "Conflict is a problem, basically, that what I } \\
\text { view it as." }\end{array}$ \\
\hline Michael & Negative & $\begin{array}{l}\text { "So because I don't like to argue I'm not } \\
\text { going to get loud." }\end{array}$ \\
\hline Cynthia & Positive & $\begin{array}{l}\text { "Everybody is different and you just got to, } \\
\text { got to understand people and why they do } \\
\text { the things they do." }\end{array}$ \\
\hline Andrew & Negative & $\begin{array}{l}\text { "If you voice your opinion, I think you } \\
\text { should be heard and [others should] take it } \\
\text { into consideration. You don't have to do it } \\
\text { right away but don't just sweep it under the } \\
\text { carpet like it never happened." }\end{array}$ \\
\hline Jeremy & Negative & $\begin{array}{l}\text { "You could be arguing and then you end up } \\
\text { saying something that's going to end up } \\
\text { hurting people." }\end{array}$ \\
\hline Elizabeth & Negative & $\begin{array}{l}\text { "[Conflict is] not something I like but it's } \\
\text { something necessary" }\end{array}$ \\
\hline Tony & Positive & $\begin{array}{l}\text { "[With] everything there's always conflict. } \\
\text { But when we live by faith, we're not limited } \\
\text { to the resources of man and the temporal } \\
\text { things of this earth." }\end{array}$ \\
\hline Julia & Negative & $\begin{array}{l}\text { "Oh! When I hear the word conflict, I'm } \\
\text { thinking negatively, like an argument." }\end{array}$ \\
\hline Zoey & Positive & $\begin{array}{l}\text { "I've come to have such a confidence, that } \\
\text { God's got it [conflict resolution], that I } \\
\text { don't worry so much about that [conflict] } \\
\text { anymore." }\end{array}$ \\
\hline Emma & Negative & "I don't like conflict-I try to ignore it." \\
\hline Antoinette & Negative & "I don't like to be wrong." \\
\hline Micayla & Positive & $\begin{array}{l}\text { "I view it [conflict] as a necessary step to } \\
\text { get to where I'm trying to go." }\end{array}$ \\
\hline Ann & Positive & $\begin{array}{l}\text { "My experience with conflict as a leader } \\
\text { teach me and I learn from it when I engage } \\
\text { in it." }\end{array}$ \\
\hline
\end{tabular}

In spite of conflict, 17 participants demonstrated compassion towards others. Seven participants demonstrated compassion by embracing diversity, seven participants showed empathy, 10 showed respect toward others, and five made an effort to reach out to others. Most participants not only reached out to others, but some also exercised their faith in God. 
Nine participants exercised their faith in God when they experienced conflict. Five participants found resolution in God, three found strength in God, and three found connection with God. Not only did some participants exercise their faith in God, but even more developed personally from the conflict experiences. Of the 12 who developed personal growth, nine built character through learning, five persevered in spite of oppositions and four were more open-minded. Seven participants provided service to others in the form of submitting to the other party, and motivating members. Four participants would rather submit to the other party when in conflict, and three participants motivated others in spite of conflict.

These findings are relevant because these approaches are not the norm, especially during church conflict. Church conflicts are sometimes quite volatile (Greenwood, 2005). Hoge and Faue (1973) found the greatest incidence of conflict occurredamong leaders, not between members of the congregation. In addition, in many cases, these conflicts have resulted in termination and loss of reputation (Breen \& Matusitz, 2012); however, the participants in my study did not share those experiences. There were thirteen participants in my study who experienced some challenges with conflict, but they were not aggressive. Of the thirteen participants in this category, seven participants preferred to avoid conflict, four felt unheard and three felt misunderstood.

As discussedin this study, the leaderscertainly encountered conflict, but they handled it in a constructive manner, or walked away from the conflict. What was unique is that their experiences in conflict showed that they learned to trust God in spite of how they would have preferred to address the conflict themselves. They spoke candidly about how different they were before having a relationship with God and concluded, in their experience, resolving the conflict God's way yielded better results. Although this response may seem uncanny, the results were valid - the participants candidly expressed their opinions and described their life experiences. The participants' tones, facial expressions, and other nonverbal characteristics conveyed the sincerity of their messages. Although the audio format could not capture nonverbal cues, I tried to capture their voice in written text by including vocal utterances such as "like" and "um." Consequently, readers can discern whether participants hesitated or paused. These nuances captured the entire message to illuminate segments of the interviews. This approach gave participants a voice and thus provides insights into resolution techniques that practitioners in the field might find useful.

Many participants referred to conventional conflict resolution techniques such as using effective communication skills and mediating disagreements; however, two principles caught my attention. First, Chris spoke about an individual "having one heart," which meant that people should not have irreconcilable differences because these differences can erupt in other areas of people's lives, including relationships. Practitioners find it helpful to learn about underlying issues so the roots of the problem can be addressed. Second, Riley spoke about listening in a manner contrary to what I learned in the communication discipline. In the communication field, listeners are encouraged to nod and even smile if appropriate to indicate they are listening (Lewis, 2012). If the smile is inappropriate, then only an intermittent nod is needed so that the speaker is aware the listener is listening (Lewis, 2012); however, Riley saw it differently. For Riley, the nod indicated the listener was not listening; in addition, Riley saw the smile as patronizing. Individuals with this perception could walk away from mediation or other third-party intervention approaches feeling unheard. Riley believed it was better to give her undivided attention, which meant looking at the speaker and listening in silence. After carefully reviewing the transcripts and composite descriptions, I ensured I drew the conclusions for each participant from his or her own language.

Examples of words connoting positive identity were "role model," "important," "impacting," and so forth. Words used to depict neutral view of self were conflicting statements, for example, "I'm pretty important . . but if someone says something negative or false, it makes me want to be that way sometimes," and neutral statements such as "Discipline plays an important role in my life. It's the way I was brought up."'Examples of words used to describe a positive view of conflict were "confidence" and "learning experience."Examples of words and phrases used to depict conflict in a negative light were "problem" and "I don't like conflict." In addition to incorporating such phrases, I used the overall context and detailed narratives to determine participants' perspectives on their conflict resolution approaches.

The results showed that 18 of the 22 participants had a positive view of themselves, and 12 had a positive attitude toward conflict. The six participants who had a positive view of themselves but seemed to have a negative attitude toward conflict still showed a willingness to resolve conflict. For example, Riley said, "I like to deal with it, talk it out ... deal with it the best I know how to, then move on." Similarly, Marianne stated, "Sometimes other things, like more serious, you know, we have to sit down and talk about it."For both men and women, more participants were positive about their approaches to conflict. Of the 14 women in the study, 11 had a positive sense of identity, and seven had a positive view of conflict. Of the eight men in the study five had a positive view of conflict. 
The lived experiences of these church leaders revealed not only the themes that emerged regarding how they viewed themselves and how they resolved conflict but also their attitude toward both topics. The verbatim examples, their intonation, facial expressions, postures, and gestures were all used to assign meaning to their experiences.

\section{Social Constructionism}

Social constructionists look at the elements of social interdependency that emerge as people construct their lives and fulfill the roles they play (Weinberg, 2014). Participants' self-constructions emerged directly from their responses. As participants described their lived experiences, they spoke about their conflict resolution approaches.

\section{Anthony mentioned,}

The men like to bleed women down. So, I'll stand with Apostle when she needs me to stand with her ... cause I know how traditional churches are and they don't believe a woman should lead. So I'll be there to say, "Look, I'm a big strong man and that's my leader. I submit to her and I'm standing here with her." So, I'm kind of there as her support as well as being that male role model.

Second, the Pastor was an Apostle, an uncommon leadership title for women in most churches (Jacobs, 2012). Elizabeth said,

Apostles-the first time I heard the word Apostle was in the book of Matthew when Jesus sent his disciples out. They were first disciples but when He sent them out in twos the next time, the next name they were given was Apostles. And Apostle is a sent one. The first Apostles, their responsibilities were to rise up the first church. I'm, I believe as an Apostle, I am in the end time revival of the church, the end time. I am in preparation for the final return of Christ and my assignment - as the scriptures said in Ephesians Chapter 4-our assignment is to bring the church-bring all into the unity of the faith, that we are no more like children tossed to and fro with every wind of doctrine-so my assignment is to teach."

The conflict resolution practices of these Jamaican church leaders were influenced by their perspectives on conflict (whether as opportunity to solve problems or as challenge), their faith in God, their ability to demonstrate compassion, their personal development, their effective strategies toward others, and their service toward others. The collective construction showed how this group resolved conflict. The participants had a spoken understanding that the Bible should be the guiding principle as they resolved conflict, even though not everyone said they applied Biblical principles. The participants used a variety of several strategies, as they resolve their differences.

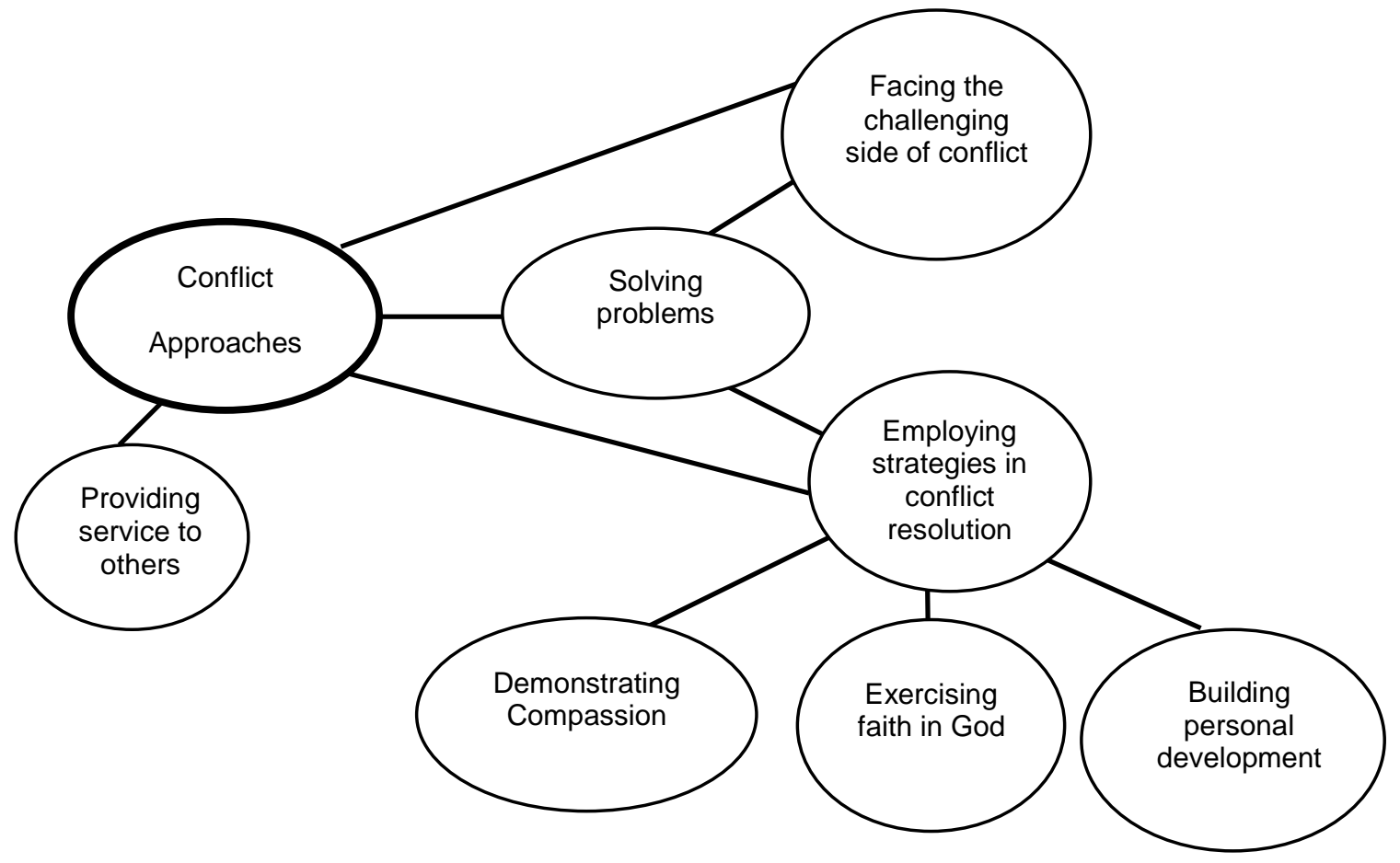

Figure 1.Emerging themes 


\section{Discussion}

Some studies have focused on conflict experiences about Jamaicans (Brown \& Johnson, 2008; LaFont, 2000; Walcott \& Hickling, 2013) and church leaders in conflict (Hadden, 1969; Krause, Ellison, \& Wulff, 1998; Schilling, 2003); however, researchers have not studied the intersection of both Jamaican heritage and church leadership. Exploring the lived experiences of Jamaicans aged 18 to 44 who were leaders, practitioners of the Apostles' doctrine, residents within South Florida, and experienced conflict provided an interesting intersection of different beliefs. In this chapter, I discuss the findings about the conflict resolution approaches that emerged through the voices of participants who shared all these experiences.

This research study provided an outlet for their thoughts and personal narratives. The dominant and idiosyncratic themes reflecting their conflict resolution approaches are noted for each individual and collectively comprise the composite description of the experiences. Their shared experiences foster an understanding of the overall phenomenon of Jamaican church leaders in conflict.

The study is significant because it unveils participants' thoughts and provides insights into their conflict resolution strategies. In addition, the study provides access to a group that may otherwise have chosen to remain silent. During the recruitment of participants, only those with whom I was acquainted accepted the invitation to participate. The other nine participants were either uncomfortable with the research because I was unfamiliar to them or perhaps for other unknown reasons. Some people prefer to be discreet with personal topics such as this one; thus, the findings from a rarely studied group may be extremely valuable.

\section{Conclusion}

The results of the study revealed how 22 Jamaican church leaders resolved their conflict experiences. Consistent with the phenomenological design, the participants spoke freely about their experiences; thus, the findings that emerged came directly from the participants. Their narratives revealed insights into how resolved their differences.

The kinds of conflicts that Jamaican church leaders experienced were not vastly different from conflicts experienced by other groups described in previous literature, but what was different was the way they navigated the conflicts they encountered. Unlike the research populations addressed in the literature review, most conflict experiences conveyed by these Jamaican participants were neither volatile nor hostile. More than half the participants in the study viewed conflict as an opportunity to solve problems, and most were optimistic about their approaches to conflict.

However, even though most had a positive attitude toward conflict, it is important to note that conflict resolution was neither simple nor easy. As Elizabeth said, "Conflict is very scary," but the participants continue to work through it.

Many of the participants used similar conflict resolution approaches and the factors affecting them. Participants admitted it was hurtful to experience the conflict, but how they dealt with the hurt and the results of the process made their experiences unique. One of these techniques included following Biblical instructions. However, following Biblical principles may not be easy; Chris said, "I'm not gonna lie, act like I like to follow Biblical values, but they're the ones that work best." Participants also applied standard conflict resolution techniques, including engaging in mediation, getting to the root of the issue, listening, and adapting to the other party. When it was beyond what they could handle, they asked God to resolve the situation for them. Others might have used similar approaches, but based on the literature review, sometimes received different results. Based on the findings, gender did not seem to make a significant difference in the approach these church leaders used.

Most participants had an overall positive approach to conflict. Individuals who had a positive sense of self had more confidence in their approaches to conflict. This was not only conveyed by how they responded to situations but also in their demeanor, tone, and other nonverbal cues as they related the message. Not all the participants presented this composure; some participants seemed unsure about their reception and boundaries in conflict situations; thus, some noted they would rather avoid conflict or keep silent. Although some may have had some reservations about engaging in conflict, they dealt with it the best way they could. Jamaican church leaders' conflict resolution approaches are influenced by solving problems, exercising faith in God, demonstrating compassion, gaining self-awareness, employing strategies in conflict resolution, providing service to others, and facing the dark side of conflict. These findings are applicable to both researchers and practitioners as they gain insight into this population. 


\section{References}

Breen, G.-M., \& Matusitz, J. (2012). Spiritual and religious communication: Intragroup conflict among southern Baptist pastors. Journal of Human Behavior in the Social Environment, 22(3), 351-374. doi:10.1080/10911359.2012.655612

Brogan, W. (2005). Heidegger and Aristotle: The twofoldness of being. Albany, NY: State University of New York Press.

Burke, K. (1966). Language as symbolic action: Essays on life, literature, and method. Berkeley, CA. University of California Press.

Burr, V. (2006). An introduction to social constructionism. London, UK: Routledge.

Cooper, R., Burton, E., \& Cooper, C. L. (2014). Wellbeing and the environment. In C. L. Cooper (Ed.),Wellbeing: a complete reference guide. Hoboken, NJ: Wiley.

Creswell, J. (2007). Qualitative inquiry and research design: Choosing among five approaches. Thousand Oaks, CA. SAGE Publications, Inc.

Ellison, C. G., Krause, N. M., Shepherd, B. C., \& Chaves, M. A. (2009). Size, conflict, and opportunities for interaction: Congregational effects on members' anticipated support and negative interaction. Journal for the Scientific Study of Religion, 48(1), 1-15. doi:10.1111/j.1468-5906.2009.01426.x

Fowler, G. (2009). Revisionist Erikson and caring for troubled congregations.Pastoral Psychology,58(5/6), 603-618. doi:10.1007/s11089-009-0252-4

Gergen, K.J. (1992). Toward a postmodern psychology. In S. Kvale (Ed.),Psychology and postmodernism(pp. 17-30). London, UK: SAGE Publications, Inc.

Gergen, K. J., \&Gergen, M. (2013). Historical social psychology. New York, NY: Psychology Press.

Giorgi, A. (2009). The descriptive phenomenological method in psychology: A modified Husserlian approach. Pittsburgh, PA: Duquesne University Press.

Greenwood, J. E. (2005). Beyond shame: Toward an understanding of church conflict. The Clergy Journal, 81(8), 3-5.

Hoge, D. R., \&Faue, J. L. (1973). Sources of conflict over priorities of the Protestant Church. Social Forces, 52(2), 178-194.

Jacobs, C. (2012). Women of destiny: Fulfilling God's call in your life. Bloomington, MN: Chosen Books.

Kvale, S., \& Brinkmann, S. (2009). Learning the craft of qualitative interviewing. Thousand Oaks, CA: SAGE Publications, Inc.

Lee, E., \& Mandelbaum, M. (1967). Phenomenology and existentialism. Baltimore, MD: John Hopkins Press.

Lewis, H. (2012). Body language:A guide for professionals. Thousand Oaks, CA: SAGE Publications.

Lock, A., \& Strong, T. (2010). Social constructionism: Sources and stirrings in theory and practice. New York, NY: Cambridge University Press.

Merleau-Ponty, M. (1945/2012). Phenomenology of perception. Delhi, India: Motilal Banarsidass Publishers.

Moustakas, C. (1994). Phenomenological research methods. Thousand Oaks, CA: SAGE Publications, Inc.

Parker, I. (1998). Social constructionism, discourse and realism. London: SAGE Publications, Inc.

Rediger, G. (1997). Clergy killers: Guidance for pastors and congregations under attack. Louisville, KY: Westminster John Knox Press.

Smith, D. (2013). Phenomenology. In E. N. Zalta (Ed.), The Stanford encyclopedia of philosophy (Online). Retrieved from https://plato.stanford.edu/entries

/phenomenology

Sokolowski, R. (2000). Introduction to phenomenology. Cambridge, MA: Cambridge University Press.

Solomon, R. C. (1972). From rationalism to empiricism. New York, NY: Harper and Row Publishers.

Van Kaam, A. (1966). Existential foundations of psychology. Pittsburgh, PA: Duquesne University Press.

Weinberg, D. (2014). Contemporary social constructionism. Philadelphia, PA: Temple University Press.

Whitson, R. P. (2014). Occupational hazards: Navigating six challenges that can harm pastors and shorten their tenure(Doctoral dissertation). Available from ProQuest Dissertations and Theses database. (Accession No. 3617447).

Zaner, R., \& Ihde, D. (1973). Phenomenology and existentialism. New York, NY: Putnam. 